PRINT ISSN 1119-8362

Electronic ISSN 1119-8362
Full-text Available Online at https://www.ajol.info/index.php/jasem http://ww.bioline.org.br/ja
J. Appl. Sci. Environ. Manage.

Vol. 24 (9) 1649-1654 September 2020

\title{
An Assessment of Socio-economic Characteristics of Slum Residents in Ilorin, Nigeria
}

\author{
${ }^{1 *}$ MAS'UD, OT; ${ }^{2}$ OLAWEPO, RA; ${ }^{1}$ AJIBOYE, JK \\ ${ }^{*}$ School of Basic and Remedial Studies, Kwara State College of Education, Ilorin, P. M. B. 1527, Ilorin, Kwara State, Nigeria \\ ${ }^{2}$ Department of Geography and Environmental Management, Faculty of Social Sciences, University of Ilorin, Ilorin, Nigeria \\ *Corresponding Author Email: tawakalituoniye@gmail.com
}

\begin{abstract}
This study examines the significance of socio-economic characteristics in making housing quality good for human living. It also examines the influence of socio-economic on the health behaviour and efficiency of man and the nation as a whole. The study was carried out with the aid of questionnaire administration, building and facility survey using purposeful sampling techniques. A total of 20 buildings in each of the fifteen identified slums were picked for questionnaire administration. Also, data were collected from related Ministries and Commission. The descriptive analysis was used to determine the vulnerability of the study area to slum condition and also to identify the extent of the decay. The descriptive analysis revealed that, the study area exhibits slum condition that has impact on socio-economic, life style and health of the residents, as well as general outlook of the environment. ANOVA was used to test whether or not there are variations in socio-economic, housing and environmental quality in all the locations. ANOVA reveals that there are significant variations in socio-economic, housing and environmental qualities among locations in the study area. Recommendations were made to guide the policy makers towards enhancing the lives of the residents of the areas, by making education affordable, public enlightenment and also to enhance the living standard of the residents by establishing industries.
\end{abstract}

DOI: $\underline{\text { https://dx.doi.org/10.4314/jasem.v24i9.24 }}$

Copyright: Copyright (C) 2020 Mas'ud et al. This is an open access article distributed under the Creative Commons Attribution License (CCL), which permits unrestricted use, distribution, and reproduction in any medium, provided the original work is properly cited.

Dates: Received: 09 August 2020; Revised: 16 September 2020; Accepted: 22 September 2020

Keyword: socio-economic characteristics, slums, housing quality, life style

Developing countries are experiencing a rapid rate of urban growth. This is manifested more in Africa where African cities are currently undergoing an urban transition at an unprecedented scale and pace; with an estimated population growth rate of $5 \%$ per year, the proportion of Africans' urban residents double every 15 years (UN, 2002). Urbanization in Africa is characterized by a high population momentum, rural urban migration and the appropriation and reclassification of land around the periphery of urban areas (Cohen, 2004). However, Africa's urban transition is occurring within the context of a vulnerable economic base exposed to vagaries and pressure of global competition (Kessides, 2005). Consequently, there is the preponderance of the large proportion of urban dwellers living in housing and environmental conditions that are clearly an affront to human dignity. Nigeria, unlike other countries in Africa does not suffer from the problem of a single, large, primate city, where all the development is concentrated. Some cities in this network such as Kano, Ile-Ife, Ibadan are pre-colonial in their defined configuration whilst others, such as Enugu, PortHarcourt and Kaduna, have their origin in colonial period. Irrespective of their origin, however, the character of a good number of Nigerian cities have been transformed in recent times especially as a result of their designation as capitals of the 36 States created between 1967 and 1976 (Mabogunje, 1980). Most cities in Nigeria are experiencing blight, slums and squalid conditions which constitute a degraded housing environment. Atere (2001) observed that a joint study by the Lagos State Government and the United Nations group revealed that 42 urban centers in Nigeria alone could be classified as slums and in dire need of upgrading or regeneration. Jinadu (2007) listed examples of slum areas in Nigeria to include Sabokarmo and Idu in Abuja, parts of Isale-eko, Ajegunle and Adeniji Adele in Lagos, Elekuro and Egbowo in Ibadan, parts of Sabon-geri, Katerengwuari Dutsenkura, Soje and Bosso in Minna and the central areas of most traditional towns including Ikom urban in Nigeria. Other highly commercialized and industrial centers in Nigeria where slums are found include Aba, Warri, Onitsha, Port Harcourt, Calabar, Enugu and so on. The urban landscape of these cities is characterized by substandard and precarious housing condition, overcrowding, poverty, crime, deplorable roads, poor sanitation, inadequate housing, water supply and poor health status. Overcrowding of people and structures especially in slums and squalid areas of built environment constitute poor housing environment.

*Corresponding Author Email: tawakalituoniye@gmail.com 
Ilorin, the capital city of Kwara State is not left out in this regards as most areas around the traditional core have characteristics resembling that of precarious and substandard housing conditions. This study however determines to assess the social economic characteristics of slum residents in Ilorin metropolis in order to look into their challenges and proffer possible solutions. The study however determines to assess the social economic characteristics of slum residents in Ilorin metropolis in order to look into their challenges and proffer possible solutions.

\section{MATERIALS AND METHODS}

Study Area: Ilorin is situated in the transitional zone between North and South of Nigeria. It is located approximately on latitude $8^{0} 30^{1}$ North and longitude $4^{0} 35^{1}$ East. Ilorin is the primate city of the middle belt up to Kaduna. It is a city between the open savannah to the north and the forest area to the south (Olorunfemi, 1983). The situation of Ilorin between the dry north and the wet south of Nigeria gave Ilorin the deserved description as the "gateway" between the north and south of the country (Adedibu, 1980) in (Olorunfemi, 1985). Ilorin is well connected and accessible through state and federal roads. It is drained by Asa River, which divides the city into two and has effects on the direction and growth of the city. A total of fifteen slum locations were identified in Ilorin metropolis (Figure 1), and all the fifteen were covered in this research work. The situation of Ilorin is between the deciduous forest of the south and the dry Savanna grassland of the north. The vegetation type is wooded Savanna grass. It grows to about ten to twelve feet during the rainy season. Ilorin is one of the fastest growing urban centre in Nigeria. Its population growth rate is much higher than for other cities in the country (Oyegun, 1983). The population of Ilorin was put at about 532088 and 781933 (NPC, 1991 and 2006 respectively). This population is occupying an area of approximately $100 \mathrm{~km}^{2}$ according to Ayinla (1999) as cited by (Olawepo and Ahmed, 1999). Ilorin is majorly a Yoruba town with Yorubas constituting about $60 \%$ of the population. The remaining $40 \%$ is shared among the Fulani, Hausa, Nupe and other ethnic minority. This heterogeneity in terms of language and ethnicity makes its culture unique (Olorunfemi, 1983). Ilorin, though developed as an administrative centre, both economic and social activities have greatly influenced its growth in recent times. The major occupations of the indigenes are farming, pottery making and weaving. A greater percentage of the people also engaged themselves in trading, some are selfemployed and a large number of the population work as civil servant, bankers, etc. Ilorin has many financial institutions which includes banks, insurance companies, co-operative societies among others.
Educational institutions such as University, Polytechnic, Colleges of Education, School of Nursing and numerous Primary and Secondary schools, are also in existence. Media houses such as, television and radio stations together with correctional services are available in the city.

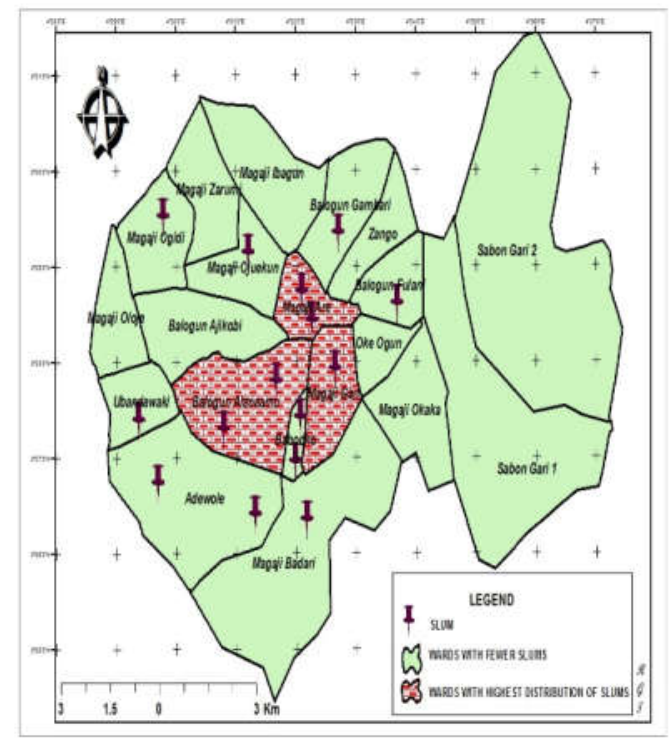

Fig 1: Ilorin Wards Showing Identified Slums

\section{MATERIALS AND METHODS}

This section contains the general procedure for the conduct of this work. It gives the types of data required for the research; describe the research design, sample and sampling method, the instrument used, methods of data collection and method of data analysis.

Types of Data Required: The type of data collected for this study include: (i) Population of slum settlements in Ilorin (ii) Map of Kwara state showing Ilorin metropolis (iii) Map of Ilorin showing identified slum areas (iv) Housing Quality of identified slums (v) Environmental Quality of the identified slums

Methods of data collection: The data used for this work were collected through the use of both primary and secondary sources.

Primary source: The primary data include reconnaissance survey, and questionnaire administration to respondents. Information regarding the age, place of origin, marital status, number of wife, educational qualification, monthly income etc. will be collected through questionnaire administration. Also data that were collected through this source include information on type of residence and type of infrastructure available. 
Reconnaissance Survey: This is important in order to locate the slum areas identified. This will help the researcher in identifying the variables to be used in designing the questionnaire in relation to the objectives of this study.

Questionnaire Administration: The questionnaire consists of close-ended questions which provide the intended respondents with options structured to capture the objectives of this study.

Secondary sources: The secondary sources of data are necessary to complement information collected from field work. This information includes: (i) Population figures of Ilorin metropolis obtained through the National Population Commission (NPC). (ii) Map of Kwara State showing the study area (iii) Map of Ilorin showing the slum settlements in Ilorin metropolis (iv) Literatures on slum and other necessary theoretical conceptual framework that were sourced from textbooks, journals and the internet network.

Sampling procedure: The population census for 2006 was used to get the total figure for Ilorin metropolis. There is no slum demarcation data in Ilorin, hence the researcher went out to count a minimum of $1.5 \%$ of the buildings in the identified slums and therefore arrived at a purposeful techniques to choose $1.5 \%$ of the buildings in each area. About fifteen slum settlement areas were identified in the study area. 300 questionnaires were distributed equally in the fifteen slum settlements as the sample size. 20 questionnaires were administered in each of the location which is
$1.5 \%$ of the total building in the areas based on close familiarity with the locations. Every fifth building was selected systematically in all the locations and only one household head was administered with questionnaire in each of the buildings selected. The units of analysis comprise the fifteen slum settlements identified in Ilorin Township. The whole fifteen slum areas were covered in this research work. Respondents for this study were household heads selected in all the fifteen slum settlements.

Methods of data analysis: Data generated were analysed using Quantitative and Qualitative methods. Quantitative method such as percentage, tables, charts as well as inferential statistics such as Analysis of Variance (ANOVA) was used to depict the relationship among socio-economic, housing and environmental characteristics.

Characteristics of Respondent in slums: Introduction: Here the characteristics of slum residents such as age, occupation, and educational qualification, monthly income as well reasons for their choice of dwelling will be discussed. Age Distribution of respondents: Age is an important factor that determines the productively as well as the dwelling of an individual. The age distribution of respondents in relation to their dwellings is shown in Table 1 . The analysis in table 1 shows that $40 \%$ of the respondents in Abayawo are within the age of $41-45$ years while $25 \%$ are 51 years and above. Gunniyan has $50 \%$ of its respondents in age group 51 years and above.

\begin{tabular}{llllll}
\multicolumn{5}{c}{ Table 1: Age of Respondent } \\
\hline Location & $>$ 30yrs & $\mathbf{3 1 - 3 5 y r}$ & $\mathbf{3 6 - 4 0 y r s}$ & $\mathbf{4 1 - 4 5 y r s}$ & $\mathbf{5 1 ~ \& ~ a b o v e ~}$ \\
\hline Abayawo & 0 & $4(20 \%)$ & $3(15 \%)$ & $8(40 \%)$ & $5(25 \%)$ \\
Adabata & $15(75 \%)$ & $3(15 \%)$ & 0 & $1(5 \%)$ & $1(5 \%)$ \\
Alapata & $2(10 \%)$ & $3(15 \%)$ & $3(15 \%)$ & $4(20 \%)$ & $8(40 \%)$ \\
Baare & $3(15 \%)$ & $2(10 \%)$ & $3(15 \%)$ & $3(15 \%)$ & $9(45 \%)$ \\
Baboko & $1(5 \%)$ & $2(10 \%)$ & $3(15 \%)$ & $6(30 \%)$ & $8(40 \%)$ \\
Gunniyan & 0 & $3(15 \%)$ & $2(10 \%)$ & $5(25 \%)$ & $10(50 \%)$ \\
Ile Film & $4(20 \%)$ & 0 & $8(40 \%)$ & $4(20 \%)$ & $4(20 \%)$ \\
Isale Koko & $3(15 \%)$ & $10(50 \%)$ & $1(5 \%)$ & 0 & $6(30 \%)$ \\
Idiape/Amule & $3(15 \%)$ & $1(5 \%)$ & $4(20 \%)$ & $6(30 \%)$ & $6(30 \%)$ \\
IsaleAluko & $6(30 \%)$ & $10(50 \%)$ & 0 & $2(10 \%)$ & $2(10 \%)$ \\
Kuntu & $6(30 \%)$ & $6(30 \%)$ & $1(5 \%)$ & $3(15 \%)$ & $4(20 \%)$ \\
Maraba & $4(20 \%)$ & $9(45 \%)$ & $4(20 \%)$ & $1(5 \%)$ & $2(10 \%)$ \\
Oja-Iya & $1(5 \%)$ & $4(20 \%)$ & $6(30 \%)$ & $4(20 \%)$ & $5(25 \%)$ \\
TaiwoIsale & $4(20 \%)$ & $5(25 \%)$ & $3(15 \%)$ & $5(25 \%)$ & $3(15 \%)$ \\
Sakele & $2(10 \%)$ & 0 & 0 & $2(10 \%)$ & $16(80 \%)$ \\
Total & $40(13.33 \%)$ & $62(20.67 \%)$ & $41(13.67)$ & $56(18.67 \%)$ & $74(24.67 \%)$ \\
\hline
\end{tabular}

Occupation of Respondents: Respondent's occupation were sampled to know the kind of work they engaged in table 2 shows the occupation of respondents. Table 2 above reveals that 203 out of 300 respondents are self-employed while 97 respondents are civil servant. Majority of the self-employed residents of identified slums are drivers while others are petty traders and tailors. The civil servant residents also belong to the junior cadre, mostly messengers and clerks except in Adabata and Ile-film where majority of respondents are teachers. 
Monthly Income of Respondent: Data concerning the income of respondents were also collected. This is necessary to test the economic status of the respondents. Table 3 below shows the distribution of income per month among respondents. Table 3 shows that, $50 \%$ of respondents in Abayawo and Idiape, $40 \%$ in Oja-Iya earns from $\$ 41-\$ 50,000$ per month. Also $45 \%$ in Gunniyan, 30\% in Ile - film earns 51,000 and above every month as income. $55 \%$ in Sakele $45 \%$ in Baare and Maraba have monthly income less than N10,000.

Educational Qualification of Respondents: Information on the educational background of respondents were sought to know their level of education attainment. Table 4 gives detail of the educational qualification of the respondents in the identified slums in Ilorin. Table 4 reveals that, the level of western educational attainment among residents in Abayawo is very low except for the $45 \%$ that had Quranic education. Of all the fifteen slum locations, Adabata seem to be the most developed in terms of educational attainment. The table also reveals that, most of the people who claimed to be educated only had primary or secondary education. For instance $35 \%$ of respondents in Alapata and Baare had only primary education, $35 \%$ of respondents in Kuntu and Maraba, $40 \%$ in Sekele had only secondary education

\begin{tabular}{lll}
\multicolumn{3}{c}{ Table 2: Occupation of Respondents } \\
\hline Location & Self Employed & Civil Servant \\
\hline Abayawo & $17(85 \%)$ & $3(15 \%)$ \\
Adabata & $7(35 \%)$ & $13(65 \%)$ \\
Alapata & $12(60)$ & $8(40)$ \\
Baare & $12(60)$ & $8(40)$ \\
Baboko & $13(65)$ & $7(35 \%)$ \\
Gunniyan & $20(100)$ & $0(0 \%)$ \\
Ile Film & $8(40)$ & $12(60)$ \\
Isale-Koko & $17(85 \%)$ & $3(15)$ \\
Idiape & $12(60)$ & $8(40$ \\
Kuntu & $13(65 \%)$ & $7(35 \%)$ \\
Maraba & $16(80 \%)$ & $4(20 \%)$ \\
Oja-Iya & $13(65 \%)$ & $7(35 \%)$ \\
Taiwo Isale & $13(65 \%)$ & $7(35 \%)$ \\
Sakele & $18(90 \%)$ & $2(10 \%)$ \\
Total & $\mathbf{2 0 3 ( 6 7 . 7 \% )}$ & $\mathbf{9 7 ( 3 2 . 3 \% )}$ \\
\hline \multicolumn{3}{c}{ Source: Fieldwork, 2018}
\end{tabular}

\begin{tabular}{llllll}
\multicolumn{7}{c}{ Table 3: Monthly Income of Respondent } \\
\hline Location & $<\mathbf{1 0 , 0 0 0}$ & $\mathbf{1 1 , 0 0 0 - 2 0 , 0 0 0}$ & $\mathbf{2 1 , 0 0 0 - 3 0 , 0 0 0}$ & $\mathbf{4 1 , 0 0 0 - 5 0 , 0 0 0}$ & $\mathbf{5 1 , 0 0 0}$ above \\
\hline Abayawo & $1(5 \%)$ & $1(5 \%)$ & $3(15 \%)$ & $7(35 \%)$ & $8(40 \%)$ \\
Adabata & $2(10 \%)$ & $6(30 \%)$ & $8(40 \%)$ & $3(15 \%)$ & $1(5 \%)$ \\
Alapata & $5(25 \%)$ & $3(15 \%)$ & $5(25 \%)$ & $5(25 \%)$ & $2(10 \%)$ \\
Baare & $10(50 \%)$ & $3(15 \%)$ & $7(35 \%)$ & 0 & 0 \\
Baboko & 0 & $6(30 \%)$ & $9(45 \%)$ & $3(15 \%)$ & $2(10 \%)$ \\
Gunniyan & $3(15 \%)$ & $1(5 \%)$ & $6(30 \%)$ & $3(15 \%)$ & $7(35 \%)$ \\
Ile Film & $3(15 \%)$ & $6(30 \%)$ & $3(15 \%)$ & $6(30 \%)$ & $2(10 \%)$ \\
Isale Koko & $2(10 \%)$ & $3(15 \%)$ & $11(55 \%)$ & $3(15 \%)$ & $1(5 \%)$ \\
Idiape/Amule & $0(0 \%)$ & $4(20 \%)$ & $4(20 \%)$ & $8(40 \%)$ & $4(20 \%)$ \\
IsaleAluko & $2(10 \%)$ & $3(15 \%)$ & $11(55 \%)$ & $3(15 \%)$ & $1(5 \%)$ \\
Kuntu & $3(15 \%)$ & $10(50 \%)$ & $4(20 \%)$ & $2(10 \%)$ & $1(5 \%)$ \\
Maraba & $9(45 \%)$ & $5(25 \%)$ & $6(30 \%)$ & $0(0 \%)$ & $0(0 \%)$ \\
Oja-Iya & $2(10 \%)$ & $3(15 \%)$ & $6(30 \%)$ & $8(40 \%)$ & $1(5 \%)$ \\
TaiwoIsale & $6(30 \%)$ & $4(20 \%)$ & $5(25 \%)$ & $4(20 \%)$ & $1(5 \%)$ \\
Sakele & $10(50 \%)$ & $6(30 \%)$ & $4(20 \%)$ & 0 & $0(0 \%)$ \\
Total & $\mathbf{5 8 ( 1 9 . 3 3 \% )}$ & $\mathbf{6 4}(\mathbf{2 1 . 3 3 \% )}$ & $\mathbf{9 2}(\mathbf{3 0 . 6 7 \% )}$ & $\mathbf{5 5}(\mathbf{1 8 . 3 3 \% )}$ & $\mathbf{3 1}(\mathbf{1 0 . 3 3 \% )}$ \\
\hline
\end{tabular}

Table 4: Educational Qualification

\begin{tabular}{|c|c|c|c|c|c|c|c|}
\hline Location & Pry Six & Sec. Edu & NCE & OND/HND & Degree & No Edu & Quranic \\
\hline Abayawo & $1(5 \%$ & 0 & $3(15 \%)$ & 0 & 0 & $7(35 \%)$ & $9(45 \%)$ \\
\hline Adabata & $1(5 \%)$ & $3(15 \%)$ & $8(40 \%)$ & 0 & $7(35 \%)$ & 0 & $1(5 \%)$ \\
\hline Alapata & $7(35 \%)$ & $4(20 \%)$ & $1(5 \%)$ & $3(15 \%)$ & $4(20 \%)$ & 0 & $1(5 \%)$ \\
\hline Baare & $7(35 \%)$ & $4(20 \%)$ & $2(10 \%)$ & $2(10 \%)$ & $2(10 \%)$ & $1(5 \%)$ & $2(10 \%)$ \\
\hline Baboko & $5(25 \%)$ & 0 & $1(5 \%)$ & $3(15 \%)$ & 0 & $7(35 \%)$ & $4(20 \%)$ \\
\hline Gunniyan & $2(10 \%)$ & $5(25 \%)$ & 0 & 0 & $0(0 \%)$ & $7(35 \%)$ & $6(30 \%)$ \\
\hline Ile Film & 0 & $3(15 \%)$ & $9(45 \%)$ & $5(25 \%)$ & $3(15 \%)$ & 0 & 0 \\
\hline Isale Koko & $5(25 \%)$ & $4(20 \%)$ & 0 & $1(5 \%)$ & $2(10 \%)$ & $4(20 \%)$ & $4(20 \%)$ \\
\hline Idiape/Amule & $2(10 \%)$ & $4(20 \%)$ & $7(35 \%)$ & $2(10 \%)$ & $2(10 \%)$ & 0 & $3(15 \%)$ \\
\hline IsaleAluko & $2(10 \%)$ & $4(20 \%)$ & $7(35 \%)$ & 0 & $6(30 \%)$ & 0 & $1(5 \%)$ \\
\hline Kuntu & $1(5 \%)$ & $7(35 \%)$ & $1(5 \%)$ & $2(10 \%)$ & $5(25 \%)$ & $2(10 \%)$ & $2(10 \%)$ \\
\hline Maraba & $4(20 \%)$ & $7(35 \%)$ & $3(15 \%)$ & $4(20 \%)$ & $1(5 \%)$ & $1(5 \%)$ & 0 \\
\hline Oja-Iya & $1(5 \%)$ & $4(20 \%)$ & $8(40 \%)$ & $3(15 \%)$ & $2(10 \%)$ & $1(5 \%)$ & $1(5 \%)$ \\
\hline TaiwoIsale & $3(15 \%)$ & $5(25 \%)$ & $2(10 \%)$ & $2(10 \%)$ & $4(20 \%)$ & $3(15 \%)$ & $1(5 \%)$ \\
\hline Sakele & $4(20 \%)$ & $8(40 \%)$ & $2(10 \%)$ & $1(5 \%)$ & $4(20 \%)$ & $1(5 \%)$ & 0 \\
\hline Total & $45(15 \%)$ & $62(20.67 \%)$ & $54(18 \%)$ & $28(9.33 \%)$ & $42(14 \%)$ & $27(9 \%)$ & $35(11.67 \%)$ \\
\hline
\end{tabular}

MAS'UD, OT; OLAWEPO, RA; AJIBOYE, JK 
Types of Material used for building: One of the criteria used in classifying building, is the kind of material used for its construction. The higher the quality of the material used, the better the building. The various types of material used for building in slums are given in table 5. From table 5, majority of the buildings in Abayawo, Alapata, Sakele and Gunniyan are built with mud wall and iron sheet roof.

\begin{tabular}{lll}
\multicolumn{2}{c}{ Table 5: Types of Material used for building } \\
\hline Location & $\begin{array}{l}\text { Mud wall/iron } \\
\text { sheet roof }\end{array}$ & $\begin{array}{l}\text { Concrete/ G.I } \\
\text { sheet }\end{array}$ \\
\hline Abayawo & $14(70 \%)$ & $6(30 \%)$ \\
Adabata & $6(30 \%)$ & $14(70 \%)$ \\
Alapata/Gegele & $15(75 \%)$ & $5(25 \%)$ \\
Baare/Pataki & $19(95 \%)$ & $1(5 \%)$ \\
Baboko/Eruda & $8(40 \%)$ & $12(60 \%)$ \\
Gunniyan & $11(55 \%)$ & $9(45 \%)$ \\
Ile Film & $17(85 \%)$ & $3(15 \%)$ \\
Isale Koko & $15(75 \%)$ & $5(25 \%)$ \\
Idiape/Amule & $8(40 \%)$ & $12(60 \%)$ \\
IsaleAluko & $15(75 \%)$ & $5(25 \%)$ \\
Kuntu & $16(80 \%)$ & $4(20 \%)$ \\
Maraba & $3(15 \%)$ & $17(85 \%)$ \\
Oja-Iya & $6(30 \%)$ & $14(70 \%)$ \\
TaiwoIsale & $8(40 \%)$ & $12(60 \%)$ \\
Sakele & $15(75 \%)$ & $5(25 \%)$ \\
Total & $\mathbf{1 7 6 ( 5 9 \% )}$ & $\mathbf{1 2 4 ( 4 1 \% )}$ \\
\hline
\end{tabular}

With this high percentage of building built with these types of material, the environment will look horrible and it can be term as slums. Even though, majority of the houses in slums are built with concrete and iron sheet roof, they are very old and this makes them to be deplorable.

Housing Types Occupied by Respondents: The different types of housing occupied by respondents of the identified slums were examined. Table 6 gives the distribution of the housing types in all the slums. From table $6,145(48.3 \%)$ of buildings occupied by respondents in slums are in compound form. This seems the commonest housing type in the identified slums. Baare, Ile-Film, Alapata/Gegele, Isala-koko and Isale-Aluko have more than half of their buildings in compound form. The next common housing type is the Barack type which occupied $33.7 \%$ of the total housing types in the slums. However, Bungalow which is a recent housing type is the least common in these areas. Abayawo and Gunniyan has the highest number of building built in barrack form. The housing types prevalent in the identified slums reveals the social class of the residents of these areas.

\begin{tabular}{lllll}
\multicolumn{5}{c}{ Table 6: Housing Types } \\
\hline Location & Compound & Bungalow & Barrack & Storey building \\
\hline Abayawo & $2(10 \%)$ & $0(0 \%)$ & $17(85 \%)$ & $1(5 \%)$ \\
Adabata & $10(50 \%)$ & $2(10 \%)$ & $5(25 \%)$ & $3(15 \%)$ \\
Alapata/Gegele & $16(80 \%)$ & $0(0 \%)$ & $3(15 \%)$ & $1(5 \%)$ \\
Baare/Pataki & $18(90 \%)$ & $2(10 \%)$ & $0(0 \%)$ & $0(0 \%)$ \\
Baboko/Eruda & $10(50 \%)$ & $1(5 \%)$ & $5(25 \%)$ & $4(20 \%)$ \\
Gunniyan & $4(20 \%)$ & $0(0 \%)$ & $15(75 \%)$ & $1(5 \%)$ \\
Ile Film & $17(85 \%)$ & $0(0 \%)$ & $2(10 \%)$ & $1(5 \%)$ \\
Isale Koko & $14(70 \%)$ & $2(10 \%)$ & $2(10 \%)$ & $2(10 \%)$ \\
Idiape/Amule & $4(20 \%)$ & $2(10 \%)$ & $10(50 \%)$ & $4(20 \%)$ \\
IsaleAluko & $14(70 \%)$ & $2(10 \%)$ & $2(10 \%)$ & $2(10 \%)$ \\
Kuntu & $12(60 \%)$ & $1(5 \%)$ & $7(35 \%)$ & $0(0 \%)$ \\
Maraba & $3(15 \%)$ & $1(5 \%)$ & $8(40 \%)$ & $8(40 \%)$ \\
Oja-Iya & $5(25 \%)$ & $3(15 \%)$ & $10(50 \%)$ & $2(10 \%)$ \\
TaiwoIsale & $6(30 \%)$ & $1(5 \%)$ & $9(45 \%)$ & $4(20 \%)$ \\
Sakele & $10(50 \%)$ & $2(10 \%)$ & $6(30 \%)$ & $2(10 \%)$ \\
Total & $\mathbf{1 4 5 ( 4 8 . 3 \% )}$ & $\mathbf{1 9}(6.3 \%)$ & $\mathbf{1 0 1}(\mathbf{3 3 . 7} \%)$ & $\mathbf{3 5}(\mathbf{1 1 . 7} \%)$ \\
\hline \multicolumn{5}{c}{ Source: Fieldwork, 2018} \\
\end{tabular}

Size of Household: The household size of each of the respondents in all the identified slums were taken. The number of people per household is represented in table 7. From table 7, $6-10$ household size is common in Baboko, Maraba, Taiwo-Isale, Kuntu and Sakele. Whereas Baare and Abayawo have the highest number of respondents whose household size is greater than 10 people. Isale-Koko and Gunniyan have the greatest share of household size from $1-5$.

Socio-Economic Characteristics: Analysis of variance (ANOVA) was used to test if there are significant differences in socio-economic, housing and environmental quality in the study area. The result
(Table 8), revealed that the calculated F-value is 85.103 with 3 and 1196 degree of freedom and at level of significance (0.05). Since the calculated level of significance $(0.000)$ is less than the table level of significance (0.05) (Table 8), it implies that socioeconomic characteristics have influence on housing characteristics. It also indicates that there are significance differences in socio-economic characteristics of respondents in the slum areas. The findings on occupation and education showed marked variations in the number of respondents that were selfemployed and those that obtained tertiary education. 


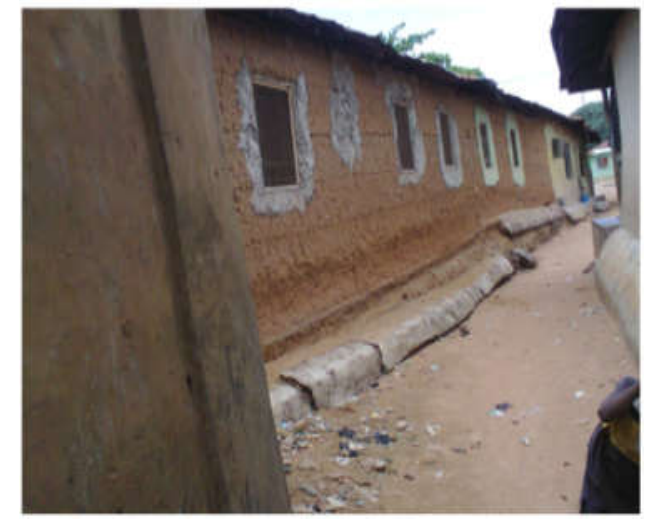

Table 2: Size of Household An example of building built with mud wall and iron roof Sources: Field work 2018

\begin{tabular}{llll}
\hline Location & $\begin{array}{l}\text { Above 10 } \\
\text { persons }\end{array}$ & $\begin{array}{l}\mathbf{6 - 1 0} \\
\text { persons }\end{array}$ & $\mathbf{1 - 5 p e r s o n s}$ \\
\hline Abayawo & $9(45 \%)$ & $4(20 \%)$ & $7(35 \%)$ \\
Adabata & $7(35 \%)$ & $4(20 \%)$ & $9(45 \%)$ \\
Alapata & $8(40 \%)$ & $8(40 \%)$ & $4(20 \%)$ \\
Baare & $10(50 \%)$ & $7(35 \%)$ & $2(10 \%)$ \\
Baboko & $2(10 \%)$ & $16(80 \%)$ & $2(10 \%)$ \\
Gunniyan & 0 & $7(35 \%)$ & $13(65 \%)$ \\
Ile Film & $6(30 \%)$ & $8(40 \%)$ & $6(30 \%)$ \\
Isale Koko & $2(10 \%)$ & $6(30 \%)$ & $12(60 \%)$ \\
Idiape/Amule & $6(30 \%)$ & $6(30 \%)$ & $8(40 \%)$ \\
IsaleAluko & $6(30 \%)$ & $9(45 \%)$ & $5(25 \%)$ \\
Kuntu & $3(15 \%)$ & $10(50 \%)$ & $7(35 \%)$ \\
Maraba & 0 & $12(60 \%)$ & $8(40 \%)$ \\
Oja-Iya & $6(30 \%)$ & $5(25 \%)$ & $9(45 \%)$ \\
TaiwoIsale & $4(20 \%)$ & $11(55 \%)$ & $5(25 \%)$ \\
Sakele & $5(25 \%)$ & $10(50 \%)$ & $5(25 \%)$ \\
Total & $\mathbf{7 4 ( 2 4 . 6 7 \% )}$ & $\mathbf{1 2 3}(\mathbf{4 1} \%)$ & $\mathbf{1 0 2}(\mathbf{3 4} \%)$ \\
\hline \multicolumn{5}{l}{ Source: Fieldwork, 2018} \\
\end{tabular}

Table 8: Analysis of variance of socio-economic characteristics

\begin{tabular}{llllll}
\hline & Sum of squares & df & Mean Square & F & Sig. \\
\hline Between Groups & 350.249 & 3 & 116.750 & 85.103 & .000 \\
Within Groups & 1640.750 & 1196 & 1.372 & & \\
Total & 1990.999 & 1199 & & & \\
\hline
\end{tabular}

Conclusion: Based on the findings above, it can be concluded that social economic characteristics and slum creation are strongly related. Socio-economic characteristics such as; educational background, income, occupation among others have great impact on slum creation in Ilorin metropolis. One can rightly conclude that slums are majorly located in the core areas and are characterized by old buildings, substandard building materials and lacking in some basic facilities and infrastructures. Also there is a strong relationship between housing facilities and environmental qualities (about 0.97) at 99\% level of significance. This implies that, as the housing facilities is increasing, so also is the environmental qualities and vice versa. There should be re- orientation of behaviour on the part of the residents to keep their body and environment clean at all time. There should be provision of basic services such as water supply and sanitary services to keep the environment clean. The government should make education avoidable for the masses to improve the educational background of the residents. The government should endeavour to establish industries in the slum areas to improve the per - capital income of residents

\section{REFERENCES}

Adedibu, A.A. (1980). Spatial pattern of housing modernisation in the traditional area of Ilorin. Nig. Geog. J., 23(1-2): 147-161

Atere, T.S. (2001). Urban slum increase in Lagos. Daily Independent, Monday, October 8, p.40.
Cohen, B. (2004). Urban growth in developing countries: A review of countries and a caution regarding the existing forecasts. World Dev., 32(1): 23-51

Jinadu, A.M. (2007). Understanding the basics of housing. A book of study notes for students in tertiary institutions. Jos University Press LTD, Jos, Plateau State Nigeria

Kessides, D. (2005). The urban transition in sub- Saharan Africa: Implications for economic growth and poverty reduction. Urban Development Union, the World Bank

Mabogunje, A.L. (1980). The development process: A spatial perspective, London, National Affordable Housing Association (NAHA) (2006). Sustainability; Policy Areas.

Hutchinson Educ. Lib. pp.182-196. Available: http://www. housingcorp.gov.uk

National Population Commission (1991 and 2006), Final results of population census of Nigeria.

Olorunfemi, J.F. (1983). Monitoring urban land use in developing countries: An aerial photographic approach. Environ. Int., 9: 27-32

Oyegun, R.O. (1983). Water Resources in Kwara State, Matanmi and Sons Printing and Publishing Limited, Ilorin

Olawepo, R.A. and Ahmed, Y.A. (1999). Factorial ecology of a traditional urban centre: The case of Ilorin, Nigeria. Centre Point, 9(1):

UN Habitat (2002) Cities without Slum. First Session; Item 6 of the Provisional Agenda. World Urban Forum, Nairobi. 